\title{
Roles of Local Media as Policy Entrepreneur in Local Policy Making Process
}

\author{
Retna Hanani \\ \{r.hanani@live.undip.ac.id\} \\ Universitas Diponegoro, Indonesia
}

\begin{abstract}
Evidence based policy has been deemed as an important element in policy processes. All government levels are expected to perform certain level of evidence-based policy making process. In order to push evidence-based policy practices, policy entrepreneurs have been considered as one of the actors that could facilitate knowledge transfer among policy makers and creating bridge between various policy actors. Policy entrepreneurs such as policy consultants, academics and local journalists could facilitate connection between planners (low level policy makers) as well as middle level policy makers with real needs of the constituencies (citizens). Within the framework of policy entrepreneurs and policy making process, the role of local media cannot be neglected. Their positions as external actor enables them to reach out to different elements of policy actors. The article examines the role of local media as policy entrepreneur in policy making process in Semarang, Central Java. Semarang has been awarded as examples of excellence in policy making process especially in terms of local development planning. Based on the case study, the article shows how Suara Merdeka a prominent local newspaper has played important role in supporting the policy agenda of Semarang Government and rarely highlights critical views in its news coverage. As such, local media tends to benefit government agenda and may not always perform its role as policy entrepreneur.
\end{abstract}

Keywords: Policy Entrepreneurs, Policy Making Process, Local Government

\section{Introduction}

Evidence based policy has been deemed as an important element in policy processes. All government levels are expected to perform certain level of evidence-based policy making process. Researches on practice of evidence-based policy in Indonesia suggest that policy makers do aware of evidence-based policy. Researches also suggest, however, that policy makers often do not implement what they know and preach. Research by Pusat Studi Hukum dan Kebijakan (PSHK) for example highlight the lack of interest from policy makers to utilize available data to support during the policy making process. In the report, PSHK shows that policy makers think positively about the existence of data. According to the informants, the research shows that policy makers think data especially statistical data from various institutions can be used as comparative data in the context of improving human resources. However, there is no integrated mechanism to link the data held by different institutions. The existing data is only stored by institution who generate the data. Even though data can be used as information for cross-sectoral/institutional policy formulation, law enforcement and legal policy formulation requires specific permit to access data provided by other institution. 
Moving beyond the availability of data especially statistical data, the research is interested to look at how policy makers implement evidence-based policy by interacting with institutions and actors outside their agency namely the media. In policy studies, the role of media is important for policy making. European Public Policy Association, for example, argues that media play important role in shaping the content and quality of policy making process. Media can advance certain policy interests that could be related to the interests of policy makers. The connection between media interests and the interest of policy makers can determine the content and framing of policy debates in the public sphere.

Furthermore, media also plays important role in mediating policy makers and the citizens. As I mentioned earlier, media can amplify policy interests from certain actors and they will be able to frame the policy debates. At the same time, media can also facilitate citizens to learn how government policy can affect their life. The media serves as an important medium between policy actors such for those who wish to influence politicians and those who monitor the reach of political debate and regulate the information flow.

Research on the role of media and policy making process has been fertile in advanced democracy. In Indonesia researches on the role of media and policy making is also considered as an emerging field. This research would like to contribute in the scholarship by looking at the role of media as policy entrepreneurs. The research also takes inspiration from the burgeoning studies on evidence-based policy in Indonesia which unfortunately remains focusing on the practice of evidence-based policy at national level. Little is known to what extent local government implements evidence-based policy making process.

Theoretically, policy entrepreneurs are important actors in facilitating knowledge transfer among policy makers. Their positions as external actors enable these actors to reach out to different elements of an otherwise fragmented institutions. The article looks at the different forms and level of policy making in Kota Semarang, Central Java. Kota Semarang has been awarded as examples of excellence in policy making process especially in terms of local development planning. Based on the case study, the article will highlight relationship between policy makers and local journalists in policy making process. The discussion will be framed under the importance of policy entrepreneurs such as policy consultants, academics and local journalists as actors that could facilitate connection between planners (low level policy makers) and middle level policy makers with real needs of the constituencies (citizens).

\section{Theoretical Framework}

Role of policy entrepreneurs are well-known in policy studies. In 1988, Nancy Roberts and Paula King, professors of public policy studies in the Administrative Science Department at Naval Postgraduate School introducing policy entrepreneur as systematic topic within policy studies. Before the introduction of policy entrepreneurs as a distinct category, the role, activities and structure of policy entrepreneur was mostly discussed under wide umbrella of interest groups in the stream of policy making process.

In her early work, Roberts and King [1] explain the roles of policy entrepreneurs are located in two general activities. The first activity is related to intellectual activities. The intellectual activities concern with idea creation and problem framing. The second activity is mobilization activities. In this activity, policy entrepreneurs focus on their effort to building support for their ideas.

Roberts and King [2] build their work based on the definition of Polsby (1984) in public entrepreneurs. According to Polsby (in Roberts and King [1]) public entrepreneurs are 
individual who specialize in problem detection and solution-finding. The ideas and problems are provided by public entrepreneurs, and technological support for solutions. Nevertheless they need partners to transfer their proposals and desired solutions from "incubation" to enactment; they need lawmakers (Polsby as cited in Roberts and King [2]). Public entrepreneurs form a "symbiotic relationship" with politicians who have to "identify and be associated with problems" because of their occasional appeals to the electorate. By entering into this relationship of exchange with political leaders, public entrepreneurs receive help in implementing policies they approve of.

Furthermore, Kingdon [3] also look at public entrepreneurs as individuals "willing to spend their money in exchange for potential policies that they support" (p. 214). While public entrepreneurs highlight concerns, advocate for one form of problem concept over another, and create solutions from their ideas, their job is that of coopering in a very complex policy process.

Regardless of the variation in defining the role of public entrepreneurs, the functions, descriptions of what public entrepreneurs actually do through the policy process can be discussed in a more general policy term. The functions of public entrepreneurs can be seen as the following:

a. Advocate new ideas and develop proposals;

b. Define and reframe problems;

c. Specify policy alternatives;

d. Broker the ideas among the many policy actors;

e. Mobilize public opinion;

f. Help to set the decision-making agenda.

In a more recent research in policy making process, public entrepreneurs is increasingly replaced by term "policy entrepreneurs". The policy entrepreneur's idea is appealing not just because it predominates reasons the role of the agency in recognizing policy reform, but also because it offers a tangible alternative to small, strictly objective portrayals of the actors involved in policy making.

Moving beyond the role of generic actor in policy making process, more recent discussion of policy entrepreneur focuses on policy entrepreneur commitment toward a policy solution, the multi-dimensional methods they use to facilitate that solution, and a collection of qualities and competencies that underpin their actions. Political entrepreneurs expose themselves in their efforts to turn political ideas into policy developments and thus challenge the status quo within the stage of policy making process. This distinguishes policy entrepreneurs from many pressure group leaders, for whom it is of utmost importance to preserve the existing institutional arrangements and power relations [4]. We may gain insights into what it takes to achieve meaningful policy reform by observing the political work of policy entrepreneurs.

The role of policy entrepreneurs cannot be overstated. In 2018-2019, Anderson, et al reviewed the role of policy entrepreneurs to legislators in the United States. Using data from a national survey of state legislators Anderson et al. [5] analyze whether entrepreneurs form the legislative agenda on disaster preparedness and recovery, what types of entrepreneurs are most powerful, and what tactics they use in their interactions with legislators. The findings suggest that lawmakers reporting contact with policy-makers are more likely to have implemented policy related to policy entrepreneurs' policy proposal. Although entrepreneurs use a number of different tactics, the research shows policymakers are especially responsive to entrepreneurs who provide fresh, credible information. This result indicates that the power of entrepreneurs lies not just in their ability to identify problems and create coalitions but also in their ability to provide elected officials with knowledge. 
Furthermore, the research also shows the complex role of policy entrepreneurs and its relation to policy process. Anderson et al. [5] argues that even though policy makers' recognition to the importance of policy entrepreneurs, elected officials do not perceive of entrepreneurs as change agents only. Policy entrepreneurs are perceived as "repositories of important information". The important role of policy entrepreneurs according to the research is stemmed not only from willingness to act and lead on important issues, but also from their ability to empower others to act. This finding confirms and emphasizes on the more older conception that "policy change require updating before they can adequately capture the dynamics of policymaking in the latter stages of the policy cycle" [5].

To make the study more concrete, in this research I look at the role of media as the policy entrepreneur. The role of media as policy entrepreneur has been widely recognized. To name a few, this research is inspired by previous work on the role of local media teaming up with local and national experts to push policy reform in Colorado [6]. In this research Crow shows how in the beginning of 1998, twelve communities decided to obtain water rights for recreational inchannel purposes such as kayaking and white-water rafting. These water rights stirred political controversy within some communities in Colorado related to spending public money, appropriate uses of water, and the role of recreation in local economies. Using a comparative case study research method, this research analyzes the role that policy entrepreneurs and local media coverage of recreational water rights played in initiating policy change in local communities. The most critical finding from this study is that in communities where citizens acted as policy entrepreneurs there was more controversy, less positive media coverage, and more media coverage early in the process. This case is important as it contradicts the assumption that local media coverage helps to highlight policy problems within communities. On the contrary to expect assumption that local media may have some yield in the policy process, the finding supports the idea that experts wield higher levels of influence than citizens in promoting policy agendas.

In context of Indonesia, the role of media and policy making process is less documented. Within the limited discussion, this research found that media play a role in shaping public perceptions about corruption eradication in Indonesia and the public's perception of the work of corruption eradication and corruption itself. From the research, we found that although the media can indeed act as a watchdog against the government, especially by carrying out investigative reporting on corruption so that it can perform its function as a counterweight, the media cannot simply reduce the rate of corruption. The reasons are the lack of public memory, weak media control, tug of interest in the newsroom, and bias in reporting on corruption eradication. As a result, even though the community considers corruption to be important to deal with immediately, they have not been moved to participate in eradicating corruption and hand over corruption eradication to law enforcers, namely the KPK and other law enforcement officials. There needs to be a rule of law so that the independence of the press as a watchdog in eradicating corruption is maintained as well as improving the quality of journalists themselves [7]. Based on the limited discussion on the role of media let alone local media in shaping policy processes, this research aims to contribute to the discussion by looking at the role of local media in Indonesia.

\section{Method}

In this section I will explain method that I employ to generate data the content and framing of policy debates in the public sphere. The research focuses on the role of two highly circulated 
local media in Semarang, Suara Merdeka. In this paper however, result is highlighted based on observation of Suara Merdeka newspaper. I conducted in depth interviews with two senior editors of Suara Merdeka and two journalists of Suara Merdeka.

\section{Result and Discussion}

Before we discuss the interview result it is imperative to look at the importance of Suara Merdeka within the context of policy and political circle in Semarang. Suara Merdeka is arguably one of the oldest newspapers in Indonesia which was born in Semarang, in the postindependence era of the Republic of Indonesia. The newspaper was first published in February 11,1950 , by press fighters led by Hetami with the initial mission to listen to the voices of the people who had just become independent.

Within the context of Indonesian political history in 1965 to1968, Suara Merdeka chose to be affiliated with the army-owned publication: Berita Yudha. In this election, Suara Merdeka is based on the belief that ABRI's loyalty to Pancasila would not be shaken. So, starting from February 14, 1966, Suara Merdeka changed its name to Berita Yudha, the Central Java edition. This condition lasted until there was a regime change, from the Old Order to the New Order, precisely on 11 June 1996. Hetami as the founder of rejected affiliation politics. According to him, newspapers must be free from the interests of certain groups. Affiliation will only cause bias in the news presented to the public. This stance is the background for the emergence of the motto "Independent, Objective, Without Prejudice" after it was re-published at the beginning of the New Order. This motto replaces the old slogan, namely: "General Daily-to Enhance the Resilience of the Indonesian Revolution". In general, the new motto describes the political direction of Suara Merdeka and with this motto, at that time Suara Merdeka was able to present itself as a modern newspaper. This is what makes Suara Merdeka relatively freer and different from affiliated newspapers which always guard the direction of certain groups or parties.

In a more recent historical development, Suara Merdeka has its own characteristics [8]. To maintain harmony between community groups, it is necessary to have moderators and communicator and that is why Suara Merdeka has been able to survive until now and has been in progress as a moderator for the people of Semarang. It requires a struggle that is not easy. As the largest regional newspaper in Central Java, Suara Merdeka contributed greatly to the political development in Central Java in general and in Semarang in particular. Suara Merdeka also acts as a moderator and communicator, meaning that it accommodates all interests of the voice of the people, including politics. Suara Merdeka Newspaper is a regional newspaper whose material is quite competitive with national newspapers, so that the content of the news is sufficient to provide information related to political conditions.

The role of Suara Merdeka during the Soeharto era was more in providing news which in line with the political context of that era. Novitasari argues that Suara Merdeka emphasized on news related to Golkar due to the centralized political system dominated by political party activity. Unhealthy political conditions affected the development of the press, so that the press system became authoritarian and the press was used as Suharto's political weapon to achieve his political goals. Therefore, various news containing the victory of Golkar's vote in several places and its merits are highlighted more than the news about the defeat of Golkar's vote in a place and its ugliness.

Furthermore, the pro status quo policy of Suara Merdeka is continued in reformation era. According to Novitasari [8], Suara Merdeka has been playing role as moderate voice of Semarang. She notes six ways in which Suara Merdeka play role as an extension of Semarang 
government. The first evidence can be seen form the active role of Suara Merdeka in supporting the dissemination of regulations produced by the Semarang City government. The government's decision comes from the Central Government, so the news presented must be based on the running of the government system. Second, Suara Merdeka Newspaper is able to help the Semarang City government, to address programs for poor people who need government assistance. This is related to Suara Merdeka's concern for the little people. Third, Suara Merdeka has been taking active role in trying to maintain the stability of the existing political conditions in the city of Semarang. In reporting, the Suara Merdeka newspaper still follows the regulations given by the government. Fourth, trying to suppress all news relating to SARA (ethnicity, race and religion) and not to report any news that may implicate SM in this category. This means that the Suara Merdeka newspaper has the initiative not to publish sensitive news. Fifth, Suara Merdeka Newspaper has a role in conveying information to the public in a polite, non-vulgar manner, not adding to and reducing, especially in the political conditions that occurred in the city of Semarang. Sixth, Suara Merdeka Newspaper is objective in reporting, but remains active in fighting for the fate of the little people. The news that is delivered as is in accordance with the source and basic input for the next publication. Based on these political convictions, Suara Merdeka still publishes political news in Semarang City which is presented in a balanced way. Suara Merdeka Newspaper tend to publish information as tool to providing educational news.

Suara Merdeka has also shown to take active role in advancing certain framing within a policy dispute. In the case of Pabrik Semen VS Kendeng citizens for example, research has shown that Suara Merdeka framed the protest in terms of religiosity rather than focusing on the political contestation. Therefore, Suara Merdeka seems in favor of one party, namely the pro cement Rembang group [9]. Furthermore, in reporting corruption case, Suara Merdeka has also shown to be timid and trying to avoid political tone in its reporting. For example, as noted by Darmawan (2014), editor of Suara Merdeka explained that in writing news related to the 2012 RAPBD bribery case involving Soemarmo, the editorial staff gave instructions to journalists, among others, first, journalists wrote facts according to those found in the field but did not develop them with opinions, no need to seek incriminating opinions, just plain and only the legal facts are raised. Second, the editorial team provides directions according to the agenda setting. In terms of political influence, Suara Merdeka has never be short in creating political class in Semarang as well as Central Java. Some of veteran journalists from Suara Merdeka has also taken important roles in the National political stage. This shows that Suara Merdeka is an important actor in framing and policy making process in general.

Based on the characteristic of Suara Merdeka in reporting critical cases in Central Java, the research moves forward by discussing its role in policy making process in Semarang. Results of interviews suggest that Suara Merdeka tends to support the policy agenda of Semarang Government. As stated by one of the informants, Suara Merdeka always tries to be balance and being moderate force within local policy context. To implement its editorial policy as moderate voice, Suara Merdeka focuses on transmitting government policy agenda and informing policy development to the public. The transmission role is further emphasized when the issues have critical implications to political process in Semarang.

The moderate position of Suara Merdeka is illustrated in the reporting of social assistance disbursement during Covid-19. The journalists realizes that overtly critical views on the disbursement of social assistance may create negative views to the current administration. As such, the journalists reported the shortcomings of the assistance program in neutral way with more emphasize in the complex challenge faced by the government. The reporting frame the government as benevolent actor that try to implement policy amid extraordinary challenges and difficult time (Covid-19). They expect public to realize that the government has been doing what 
they can regardless of the enormous challenges. Critical views on the implementation of Covid19 assistance program are reported albeit minimally. The 'critical voice' is further framed as suggestion for a better implementation rather than voicing grievance from citizens affected by Covid-19 or those who do not receive the assistance program.

In terms of development planning, the newspaper stresses the importance of constructive inputs (kritik yang membangun) as main indicator for reporting. For example, in the case of road development in one neighborhood in South Semarang. The residents have filed objections and demanded the Semarang government to revise the road plan. The demand creates tension between the residents and the government. Aware of the critical situation, the newspaper decides to highlight soft criticism from one of community leaders. The critique highlighted in the reporting includes acceptance from the residents which accompanied by indirect demand. For example, the news stated: "He (the leader) said that he actually welcomed the intention of widening the road by the Semarang Government. It's just that because the project has suddenly stopped for a while, the road construction has become neglected and his side has been affected. The access road is also dredged using this method for the construction process of road widening". The choice of reporting illustrates how Suara Merdeka tries to voice citizens' demand indirectly.

\section{Conclusion}

Theoretically, policy entrepreneurs are important actors in facilitating knowledge transfer among policy makers. Their positions as external actors enable these actors to reach out to different elements of policy actors. The article examines the relationship between policy makers and local journalists in policy making process including the different role of local media as policy entrepreneur in Kota Semarang, Central Java. Kota Semarang has been awarded as examples of excellence in policy making process especially in terms of local development planning. Based on the research, the article concludes Suara Merdeka a prominent local newspaper has played important role in supporting the policy agenda of Semarang Government and rarely highlights critical views in its news coverage. As such, local media tends to benefit government agenda and may not always perform its role as policy entrepreneur.

\section{References}

[1] N. Roberts and P. King, "Policy Entrepreneurs: Catalysts for Innovative Public Policy.," Acad. Manag. Proc., vol. 1988, no. 1, pp. 313-317, 1988.

[2] N. C. Roberts and P. J. King, "Policy entrepreneurs: Their activity structure and function in the policy process," J. Public Adm. Res. Theory, vol. 1, no. 2, pp. 147-175, 1991.

[3] J. W. Kingdon and E. Stano, Agendas, alternatives, and public policies, vol. 45. Little, Brown Boston, 1984.

[4] E. Petridou and M. Mintrom, "A Research Agenda for the Study of Policy Entrepreneurs," Policy Stud. J., vol. 0, no. 0, pp. 1-25, 2020.

[5] S. E. Anderson, R. A. DeLeo, and K. Taylor, "Policy Entrepreneurs, Legislators, and Agenda Setting: Information and Influence," Policy Stud. J., vol. 48, no. 3, pp. 587-611, 2020.

[6] D. A. Crow, "Local media and experts: Sources of environmental policy initiation?," Policy Stud. J., vol. 38, no. 1, pp. 143-164, 2010.

[7] D. L. Natalia, "Media Massa dan Pemberitaan Pemberantasan Korupsi di Indonesia," $J$. Antikorupsi Integritas, vol. 05, no. 2, pp. 57-73, 2019.

[8] R. Novitasari, "Peran Koran Suara Merdeka Dalam Mengapresiasikan Kondisi Politik Di Kota 
Semarang Tahun 1982-1999," J. Indones. Hist., vol. 1, no. 2, 2012.

[9] M. Solihin and N. Kurnia, "Pemaknaan Konflik Pabrik Semen Kendeng dalam Framing Media Berita," J. Ilmu Komun., vol. 15, no. 1, pp. 16-27, 2017. 